\title{
THREE BUCKETS SYSTEM FOR FOOD STREET INDUSTRY. CASE STUDY IN BANDUNG AND PALEMBANG
}

\author{
Dony Riyadi, Yusuf Kusuma Bangun \\ Palembang Polytechnic of Tourism \\ Palembang City \\ dony_riyadi@yahoo.com,ucup_bintan@yahoo.com
}

\begin{abstract}
Food Street has become an Industry in Indonesia with growth Manificiently year by year, Many Business Cities such as Bandung- Capital City of West Java and Palembang-Capital City of South Sumatera, Food street industry in Indonesia is very rapidly development, All major cities in Indonesia have main area for food street vendors, and has become part of Lifestyle, Cleanliness is a Important issue that Domestic and Foreign Tourists are very detail mentioned on this matter, Food Hygiene, This research emphasizes the Solution of Cleaning Equipment and Cooking Hygiene Problems, Three Buckets System is adopted from cleanliness procedure on cruise ship, with the Wash - Rinse and Sanitize System then the Hygiene Guarantee will be more effective.Based on 6 (six) Principles of Food Hygiene,one of mentioned is Hygiene of Cookware and Dinner wares, Use of the Three Buckets System at a Street Vendor using the Portable (Three Bucket System) Tool to make it easier for Street Merchants to use the tool at a cost that is not large. Of the 250 Respondents interviewed 90\% stated that cleanliness is very important in considering buying decisions in the street vendors. Some obstacles faced by Food Street Vendors in maintaining cleanliness are the availability of clean running water, Places and costs incurred in making washing Equipment, with Three Buckets System is expected to be a solution in maintaining cleanliness so that customer health can be maintained with cleanliness of Cooking Equipment and Utensils till Dinner Wares.
\end{abstract}

Keywords: Food Hygiene, Food Street Industry, Wash-Rinse-Sanitize

\section{INTRODUCTION}

In 2018, the Ministry of Tourism of the Republic of Indonesia targets 12 (twelve) million foreign tourists to come to Indonesia, it is a challenge for the Tourism Industry to prepare itself as a good host, complementing the facilities Product Services both in Hospitality, Restaurants, Places of Interest and International Standards for comfort and security of tourists can be achieved. Year 2016, Minister of Tourism Dr. Arief Yahya proclaimed the establishment of 10 (ten) New Tourism Destination namely Lake Toba (North Sumatra), Belitung (Babel), 
Tanjung Lesung (Banten), Thousand Islands (DKI Jakarta), Borobudur (Jateng), Mount Bromo (East Java), Mandalika Lombok (NTB), Komodo Island (NTT), Wakatobi National Park (Southeast Sulawesi), and Morotai (North Maluku), as a driver and promoting natural resources and local tourism supporting wisdom.

Ministry of Tourism through UPT (Technical Implementation Unit) in 6 (six) High School and Polytechnic Tourism (STPP) namely; NHI Bandung Tourism High School, Bali Tourism College, Palembang State Tourist Polytechnic, State Tourism Polytechnic of Medan, State Tourism Polytechnic of Makassar, State Tourism Polytechnic of Lombok consistent in devotion to Society for Tourism extension throughout Indonesia. Research from High School Parisiwata NHI Bandung and Palembang Tourism Polytechnic of Paying attention to health and hygiene of Food in this case Street Vendors as Supporting Tourism Business, Since Year 2012 High School Tourism NHI Bandung doing Community Service in Area Tourism Cihampelas and Cipaganti latest is April 5, 2018 Palembang State Polytechnic conducted Tourism Extension activities in West Coast District of Lampung Province and Date 16 - 19 April in Belitung Regency, one of the Materials presented on Tourism Technical Guidance is Culinary as a Supporter of Macro Economy that is the formation of Gastronomy City, Indicator for Gastronomy City's predicate is Hygiene and Health at the Food Street Industry.

The notion of street vendors is that people with relatively small capital / little attempt to produce goods and services to meet the needs of certain consumer groups in society. The effort was undertaken at places considered strategic in informal enterprises (eridian in Sudaryanti, 2000).

Tourism in question is Hospitality and Homestay, Tourism Business, Tour and Travel and Culinary Tour that has become a special tourist attraction for tourists, from about 100 respondents Wisatwan Dosemstik and Manca Negara there are about 40 people or $40 \%$ of tourists are eager to try the local wisdom one of them is Culinary. On December 14, 2012 the Ministry of Tourism introduced 30 Indonesian Culinary Icons from Sabang to Merauke consisting of a variety of flavor-rich Nusantara cuisine from Indonesian spices.

Attractiveness of the Food and Beverage Business in Indonesia lies to the flavors of Spices and Herbs that are very diverse, Hundreds of Varieties of Food and Beverage Variations are presented alongside the Main Streets in Major Cities in Indonesia, ranging from Traditional Snack Foods to Food Modified Europe and Asia adjust the contents of the purchaser's pockets, the seller is called a Walker Trader, According to Big Indonesian Dictionary that the Clerk of Five-Fifth is a seller on the sidewalk, which is Five Feet.

Year 2017 recorded Great City such as Bandung - Cihampelas District according to District there are about 200 (Two Hundred) Street Vendors along Jalan Cihampelas and Palembang - Jakabaring area according to local government data there are more than 250 Vendors foot Lima is around Jakabaring, the area is a Domestic or Local Travelers Destinations, Kiki Vendors Eating and Drinking is a fertile tumbu in the city of Bandung and Palembang because this business reaches the Bottom Consumer with a variety of flavors.

Food and Beverage Hygiene is a concern to win the Middle and High Buyer Market, The Visiting of International Travelers for the Back Packer category (with Limited funds) continues to increase this target Government through the Ministry of Tourism in reaching 7 (seven) Million tourists in Year 2019, Consumer Level 
Intermediate have paid attention to food hygiene, hygiene of food utensils and cooking utensils, environmental hygiene where street vendors such food and drink. Law No. 942 / MENKES / SK / VII / 2003 Chapter III Equipment on Article no 3 (1) Equipment used to process and serve snack foods should be in accordance with their provisions and meet sanitation hygiene requirements. (2) To safeguard the equipment as intended in paragraph (1): a. Used equipment is washed with clean water and with soap; b. then dried with a clean dryer / wipe c. then the clean equipment is stored in place which is free of pollution. (3) It is forbidden to reuse the equipment designed only for disposable.

The law is very clear that the cleanliness of serving equipment and cooking utensils is part of food sanitation if it is violated, then a Criminal Trader may be sentenced to Criminal Punishment because it concerns the Health and Human Soul. To meet the need for sanitation Equipment Saji and cooking it is necessary a simple tool Portable easy to carry because Pedag Kaki Lima one factor is like moving to follow the many consumers who buy.

This research will produce a tool for washing up tools and cooking utensils by using the Three Buckets System or a washing system using three buckets with WASH - RINSE - SANITIZE concepts, a very simple and repairable portable tool and upgrading to be more effective and efficient

Here the problem analysis can be stated as follow:

A. What is the important role of hygiene in terms of buying and selling Food and Beverage decisions at the Street Vendors?

B. How is the Effectiveness of this Three Buckets System Appliance Acceptable by Food and Beverage Street Vendors?

\section{FUNGSI THREE BUCKET SYSTEM}

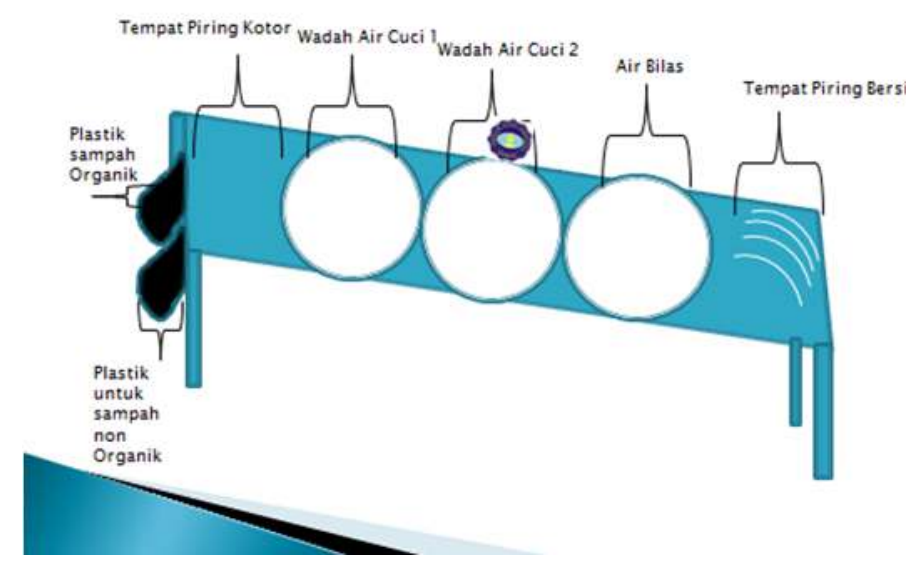

Figure 1. Three Buckets System For Food Street Industry

\section{METHODOLOGI}

This Research Title is THREE BUCKETS SYSTEM FOR FOOD STREET INDUSTRY- Case Study on Cihampelas Street- Bandung City- West Java and Jakabaring - Palembang City - South Sumatera . This study has advantages as a 
preliminary study, there will be further research related to the effectiveness of the tool to be accepted by the Foot Dealer both from Material, Size, Price and Ease of getting the tool.

\section{Research Method}

This Reseach used many methods, such as :

a. Questioner; Questionnaires were conducted in Bandung and Palembang, as many as 200 respondents filled out Questionnaires with details of 100 in Bandung and 100 in Palembang, who had enjoyed Food and Drink at Street Vendors.

b. Interview; Interviews were conducted with several Professions: Lecturers, Entrepreneurs, Private Employees to the Students. Interview not only to the Consumer but also to the Trafficker to Trial the Three Buckets System Tool how far the effectiveness of this Cleaning Tool.

c. On Field study observation; Field observation activities are carried out to be able to know the reality of things faced by street vendors who do not have access to water flows when doing dishwasher / tool and cooking utensils.

\section{Time and Premises of the Research;}

This Research was done in January - March 2014 in Bandung City dan January - March 2018 Palembang City. Premises This Research took 2 Places of Study Case: Bandung city Case Study taken on Cihampelas StreetWest Java and Palembang City Case Study taken around Jakabaring - South Sumatera

\section{Research Result}

This Research is to produce Three Buckets System portable tools for food street vendor whose don not have an accessibility to running hygiene Water, this tool is made in order to be brought wherever the street vendors food and drink or something to be clean place plates and cookware can be guaranteed and efficient use of water, but this tool will continue to be made and modified in order to be accepted by street vendors.

\section{LITERATURE}

Food Street has become an Industry because the region's revenue for this industry is quite large, and now Food street has become the main destination of tourists, as food tourism and will continue to grow, the purpose of eating consumers on Food Street has some Nostalgia, want to try something interesting, and not a few also want a new atmosphere that has its own sensation

In Canada and the USA more than half of the average family food budget is now spent on dining out. This Means that many people are being exposed to new foods and better quality foods. As a result, restaurants continue to open and expand, plus eating out encourages consumers to be more experimental and try more exotic foods. Consumers look for 'weekday convenience' and 'weekend experiences' and a farm is a great place to go for such an experience. Many schools are now encouraging young people to visit farms as learning experience to comprehend were 
their food comes from and have a fun experience in Natural environment. This in turn creates 'pester power', where children encourage their parents to take them to the farm and spend more time in countryside.(j.Stanley and L.Stanley, P 7 :2015) Hygiene and health have come to the attention of consumers, food poisoning or an unclean place will damage the business itself, the need for health and hygiene has become the latest issue that Food Street Vendors must be aware of in winning larger markets Sanitation may help prevent a food poisoning outbreak. Most of the foodrelated illnesses that are caused by restaurants are the result of unsanitary food handling practices. A third is that main training safe and sanitary conditions can help preserve food quality.Storing, preparing or serving food is unsanitary conditions could adversely affect the food quality and taste. Also, sanitation protects the brand name. Having just one case of food poisoning can destroy the business, so training the employees to follow safe food handling practices is necessity. Keeping things clean and sanitary will gain the turst of customers and employees. (Barbara Almanza, Ph.D.,RD and Richard Ghiselli, Ph.D., P 4 : 2012). The concept of the Three Buckets System is adopted from the crucial cleanliness system in cruise ships to monitor the cleanliness of serving equipment in order to avoid food contamination; this concept is applied in the Food Street Industry because hygiene and health is the right of every consumer protected by law in the Republic of Indonesian.

Manual warewashing is typically performed in a sink that has at least three compartments. The first compartment is used for washing, the second for rinsing, and the third compartment is used for sanitizing. Each compartment must be large enough to accommodate immersion of the largest equipment and utensils used in your food establishment. If equipment or utensils are too large for the warewashing sink, they must be cleaned and sanitized using mechanical dishwashing machine or alternative manual warewashing equipment, such as high-pressure detergent sprayers, low-or line-pressure spray detergent foamers, or other task-specific cleaning equipment. The manual warewashing sink must be equipped with sloped drain boards or dish tables of adequate size to store soiled item prior to washing, and clean items after they have been sanitized. Hot and cold portable water must be supplied to each compartment of the sink, and the sink should be cleaned and sanitized prior use. Equipment and utensils are washed in the firstcompartment with warm water and an effective cleaning agent. Washing removes visible food particles and grease. The correct amount of detergent, based on the quantity of water used in compartment, should always be used. The temperature of the wash solution must be maintained at less than $110^{\circ} \mathrm{F}\left(43^{\circ} \mathrm{C}\right)$ unless a different temperature is specified by manufacturer of cleaning agent. (David McSwane,H.S.D; Nancy R.Rue, Ph.D.; Richard Linton,Ph.D. P 279 : 2003).

In the future, that Food Street Industry has a certificate approaching HACCP (Hazard Analysis Critical Control Point) as the highest certificate in food industry, the Government is expected to be directly involved in fixing the cleanliness and healthiness of the Food Street industry so that a region can become a Gastronomy City implemented by UNESCO (United Nations Educational, Scientific, and Cultural Organization).

The purpose of food industry management in ensuring food security. The HACCP (Hazard Analysis Critical Control Point) and its development are recognized to meet some of the food industry's management goals to provide assurance that the 
industry has: Producing safe food products at all times; Provide proof of production system and safe product handling; Provide a sense of confidence in the manufacturer of its security guarantees; Provide satisfaction to customers conformity to national and international standards; Meets government standards and regulations; Use of resources effectively and efficiently.

Food poisoning can be caused by various things one of which is the bacteria that contaminate the food, the following are the kinds of diseases caused by bacteria

\section{BACTERIA}

\begin{tabular}{|c|c|}
\hline Disease : Bacteria & Typical a result of \\
\hline $\begin{array}{l}\text { Salmonellosis } \\
\text { (Salmonella) }\end{array}$ & $\begin{array}{l}\text { Improper handling and cooking of eggs, } \\
\text { poultry, and meat; contaminated raw } \\
\text { fruits and vegetables } \\
>\text { Highly contagious- must report to } \\
\text { person in-charge } \\
>\text { Flies, water, and foods contaminated } \\
\text { with fecal water } \\
>\quad \text { Improper handling ready-to-eat foods } \\
\text { and time/temperature abuse } \\
>\text { Found in the intestine of humans, wash } \\
\text { your hands! } \\
>\text { Highly contagious-must report to } \\
\text { person-in-charge }\end{array}$ \\
\hline $\begin{array}{l}\text { Harmorrhagic colitis } \\
\text { (E.coli) }\end{array}$ & $\begin{array}{l}\text { Undercooked ground beef, } \\
\text { unpasteurized juice/cider and dairy } \\
\text { products, contact with infected animals } \\
\text { and cross-contamination } \\
>\text { Highly contagious - must report to } \\
\text { person-in-charge }\end{array}$ \\
\hline Bacillius cereus & $\begin{array}{l}\text { Improper holding, cooling, and } \\
\text { reheating rice products, potatoes, and } \\
\text { starchy foods }\end{array}$ \\
\hline Campylobacteriosis & $\begin{array}{l}\text { Time and temperature abuse, garlic-and- } \\
\text { oil mixtures, improperly sautéing and } \\
\text { holding sautéed onions, serving home } \\
\text { canned products and improperly cooling } \\
\text { leftovers, improper processing and } \\
\text { storing of canned goods }\end{array}$ \\
\hline Clostridium perfringens & $\begin{array}{l}\text { Not cooking food, especially chicken, to } \\
\text { proper internal temperatures, cross- } \\
\text { contamination and using unpasteurized } \\
\text { milk and untreated water }\end{array}$ \\
\hline
\end{tabular}




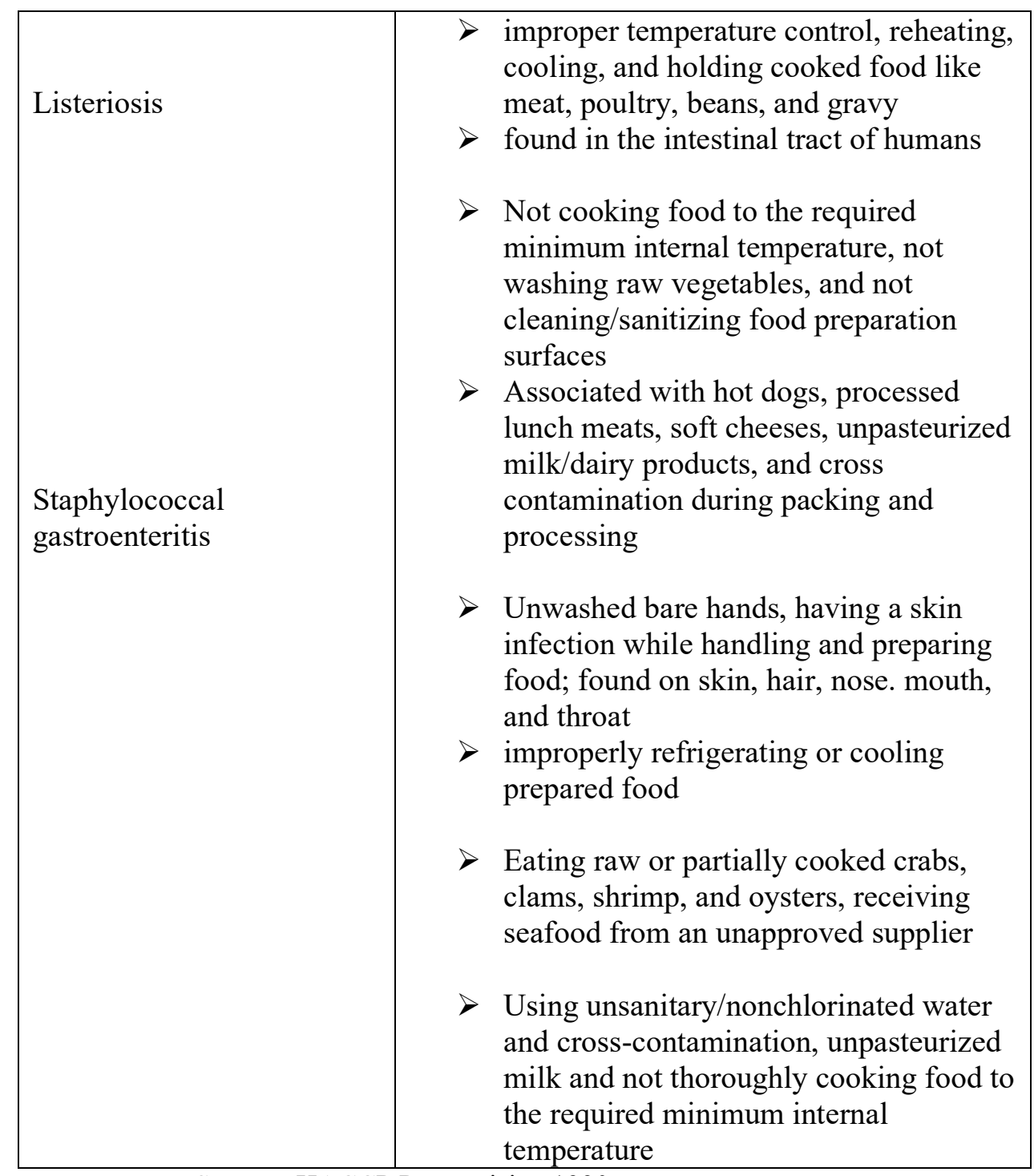

Source : HACCP Prerequisite, 1990

\section{RESULTS AND DISCUSSION}

What is the important role of hygiene in terms of buying Food and Drink decisions at the Street Merchants?

Education on Consumers is necessary because, as long as there is demand, there is Supply Growth. The most important education is to use implementation approach such as the example of holding a national seminar on health and hygiene of food and beverage on health, conducting Hygiene and Sanitation Competition at Vocational High School and High School level, Polytechnic and University of Food Street consumption demand is very high, recorded growth of street vendors in Cihampelas, Bandung and Jakabaring, Palembang from last 2 years. This research only took $10 \%$ sample from the number of Food street vendors who are on Cihampelas Street and in Jakabaring with the data as follows: 
Table 1. Data of Food Street Vendor for Case Study- Three Buckets System

\begin{tabular}{|c|c|c|c|}
\hline NO & Food Street Vendor & Bandung & Jakabaring \\
\hline 1 & PECEL LELE & 10 & 3 \\
\hline 2 & $\begin{array}{c}\text { NASI UDUK DAN } \\
\text { SEAFOOD }\end{array}$ & 5 & 2 \\
\hline 3 & NASI GORENG & 5 & 3 \\
\hline 4 & BAKSO & 10 & 2 \\
\hline \multicolumn{2}{|c|}{ TOTAL } & 40 & 10 \\
\hline
\end{tabular}

Source : Author, 2018

Nowadays consumers are good at choosing a street trader, smart in choosing in the sense that consumers are more selective before deciding to buy food products in street vendors, in addition to considering the selling price, consumers also pay attention to food hygiene and health, from some interviews conducted to consumers The middle class ( 5 to 5 million rupiahs) vendors per month of 50 people found that $60 \%$ prioritize the cleanliness and health of the Area, Dinner wares, Raw Food. Proving that consumers have chosen and street vendors are expected to keep pace with the changing times, the need for street vendors will continue to increase, and education is not just for the Foot Vendors but for the consumers it is necessary.

The growth of street vendors in big cities such as Bandung and Palembang continues to grow in line with economic growth in the city of magnitude that attracts urban people, as reported by Metronews.com from year to year has increased by $10 \%$ in Reply is rumored that the increase of Street Vendors due to the economic pull power in the Big City.

Tabel 2. The Consumer desicion Food Street in Bandung

\begin{tabular}{|c|c|c|c|}
\hline NO & Component & N & \% \\
\hline 1 & Price & 68 & 27,2 \\
\hline 2 & Taste & 75 & 30 \\
\hline 3 & Accessibility & 50 & 20 \\
\hline 4 & $\begin{array}{c}\text { Hygiene and } \\
\text { Sanitation }\end{array}$ & 57 & 22,8 \\
\hline \multicolumn{2}{|c|}{ TOTAL } & 250 & 100 \\
\hline
\end{tabular}

Source : Author, 2014

Socialization of the health and hygiene understanding of Food and beverage for the people to directly affect the supply of Food Street industry products and services will continue to grow. Consumers can choose which Food Street serves the Government's standardized Products and services; unchanging merchants fold up by itself.

Tabel 3. The Consumer decision Food Street in Palembang

\begin{tabular}{|l|l|l|l|}
\hline NO & Components & $\mathrm{N}$ & $\%$ \\
\hline
\end{tabular}




\begin{tabular}{|c|c|c|c|}
\hline 1 & Price & 60 & $30 \%$ \\
\hline 2 & Taste & 60 & $30 \%$ \\
\hline 3 & Accessibility & 20 & $10 \%$ \\
\hline 4 & $\begin{array}{c}\text { Hygiene and } \\
\text { Sanitation }\end{array}$ & 60 & $30 \%$ \\
\hline \multicolumn{2}{|c|}{ TOTAL } & 200 & 100 \\
\hline
\end{tabular}

Source : Author, 2018

Table 4. Consumer expectation of Sanitation of Food Street Vendors

\begin{tabular}{|c|c|c|c|}
\hline NO & Cleanliness & Agreed & $\%$ \\
\hline 1 & Personal & 46 & 18,4 \\
\hline 2 & Ingredients & 34 & 13,6 \\
\hline 3 & Equipment & 58 & 23,2 \\
\hline 4 & Cooking Method & 43 & 17,2 \\
\hline 5 & Food Store & 40 & 16 \\
\hline 5 & Premises & 30 & 12 \\
\hline & Total & 250 & 100 \\
\hline
\end{tabular}

Source : Author,2018

How is the Effectiveness of this Three Buckets System Appliance Acceptable by the Food street vendors?

Three Buckets System was introduced to Street Vendors to minimize food contamination caused by the lack of clean food and beverage equipment for bacteria; Chemical substances can be minimized by WASH - RINSE - SANITIZE system.

This tool is still very simple, aimed at street vendors who do not have the accessibility of clean water that flows in accordance with standards of hygiene and health, Lots of street vendors are located on the installation of the water so it takes a simple dishwashing equipment but can make the plate become cleaner and prevent Cross Contamination.

WASH: Preliminary washing when dirty dishes are cleaned by using clean water without laundry soap, it aims to remove excess dirt during the piling process, for the effectiveness of water and soap use which will also affect the environment if disposed of after multiple times

RINSE: Wash using WATER + SOAP WASH, cleaning process to remove residual Oil still attached to cutlery, kill bacteria and remove odor to be more fresh

SANITIZE: Rinsing after plates / equipment is washed with soap, it is necessary to remove the residual soap that is still attached to the serving equipment, as it is known that soap contains harmful chemicals when it enters the body for long periods of time. 


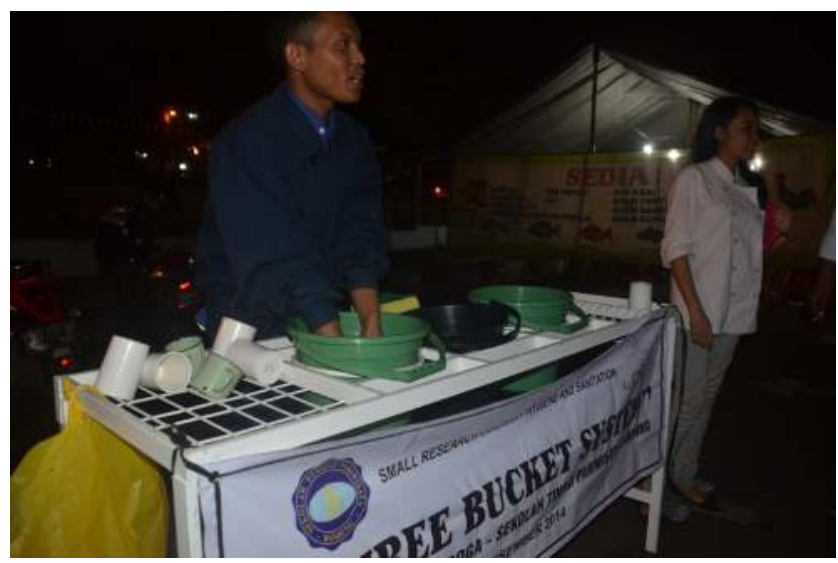

Figure II

Trial of Three Bucket System in Bandung Source : Author, 2018

Washing Soap The plates used every day are very important role. The content contained in soap can lift fat and kill germs on dirty dishes, although it looks safe because it is used in everyday life even to wash fruits and vegetables though, apparently this is not entirely true, soap is still a cleaning product that contains chemicals certainly not good for health. In louded from Find Health Tips, here are some of the ingredients contained in dishwashing soap that can lead to cancer.

a. APE's (Alky Phenoxy Ethanols) Researchers have found the presence of APE on dishwashing soap. This substance turned out to activate estrogen recipients and stimulate the growth of breast cancer cells in the human body;

b. Dyes The soap uses a dye called Coal Tar Dyes. This dye contains arsenic, cadmium, and toxins that can absorb into the skin

c. Cocaide Substance Dea Dishwashing Soap Plates can produce foam due to the Cocaide Dea Substance, this material is a synthetic chemical used to substitute coconut oil. Unfortunately, this material is not good for the health of the body

d. DEA (diethanolamine), MEA (monoethanolamine) and TEA (triethanolamine) Dishwashing soap also contains 3 These harmful substances, if these three substances are used continuously for a long time, will increase the risk of cancer, Not only that if this substance is in direct contact with the skin, will cause skin burn and irritation

Dishwashing soap is very harmful to the body when consumed over long periods of time, but some of the problems faced by Food Street vendors are a lack of understanding of hygiene and health and the high cost of hygiene and health, from Water Accessibility, Hygiene Certificates, all of which require a lot of money, especially clean water, Food Street vendors are still many who do not have access to clean water that flows, because a place away from the installation of clean water that flows the following is the response of Food Street Vendors who have difficulty in implementing cleanliness of the appliance and cooking ware. 
Table 5. Threats of Hygiene and Sanitation of Food Street Vendor

\begin{tabular}{|c|c|c|c|}
\hline NO & Component & Agreed & $\%$ \\
\hline 1 & Price of Water & 20 & 50 \\
\hline 2 & Availability & 5 & 12,5 \\
\hline 3 & $\begin{array}{c}\text { Lack of } \\
\text { Acknowledge }\end{array}$ & 5 & 12,5 \\
\hline 4 & $\begin{array}{c}\text { Expensive of } \\
\text { Hygiene }\end{array}$ & 10 & 25 \\
\hline \multicolumn{2}{|c|}{ TOTAL } & 40 & 100 \\
\hline
\end{tabular}

Source : Author, 2018

Food Street Vendors both in Bandung, and in Palembang have difficulty in accessibility of clean water, 1 Tank of 10 Liter for Rp.4000 (Four Ribu Rupiah) and rata2 in a day can spend about 20 Liter to wash dishes and Cookware, this resulted less clean the laundry plates because water is used to save for water consumption can be maintained, a day Food Street Vendor can wash as much as 100-150 Plates and Glasses, with circumstances like this do not allow the plate to be clean, the water is used only then the dirt is plates and glasses are still some dirt and smelly contamination from previous foods

Table 6. Consuming Water unuse Three Bucket System

\begin{tabular}{|c|c|c|c|}
\hline NO & Amount of Plates & $\begin{array}{c}\text { Bucket } \\
\mathbf{1}\end{array}$ & $\begin{array}{c}\text { Bucket } \\
\mathbf{2}\end{array}$ \\
\hline $\mathbf{1}$ & $\mathbf{1 0}$ & $\mathbf{5}$ & $\mathbf{5}$ \\
\hline $\mathbf{2}$ & $\mathbf{3 0}$ & $\mathbf{5}$ & $\mathbf{5}$ \\
\hline $\mathbf{3}$ & $\mathbf{5 0}$ & $\mathbf{5}$ & $\mathbf{5}$ \\
\hline $\mathbf{4}$ & $\mathbf{7 0}$ & $\mathbf{5}$ & $\mathbf{5}$ \\
\hline \multicolumn{2}{|c}{ TOTAL } & & \\
\hline
\end{tabular}

Source : Author, 2018

Table 7.Consuming Water use Three Bucket System

\begin{tabular}{|c|c|c|c|c|}
\hline NO & $\begin{array}{c}\text { Amount of } \\
\text { Plates }\end{array}$ & $\begin{array}{c}\text { Bucket } \\
\text { Wash }\end{array}$ & $\begin{array}{c}\text { Bucket } \\
\text { Rinse }\end{array}$ & $\begin{array}{c}\text { Bucket } \\
\text { Sanitize }\end{array}$ \\
\hline $\mathbf{1}$ & $\mathbf{1 0}$ & $\mathbf{5}$ & $\mathbf{5}$ & $\mathbf{5}$ \\
\hline $\mathbf{2}$ & $\mathbf{3 0}$ & - & - & $\mathbf{5}$ \\
\hline $\mathbf{3}$ & $\mathbf{5 0}$ & - & - & $\mathbf{5}$ \\
\hline $\mathbf{4}$ & $\mathbf{7 0}$ & - & - & $\mathbf{5}$ \\
\hline \multicolumn{2}{|c|}{ TOTAL } & & & \\
\hline
\end{tabular}

Source : Author, 2018

This Portable tool will be modified to reach the effectiveness, and accepted by Food Street Vendors such as the standard of Hygiene and Sanitation for wahs basing should have warm water $40^{\circ} \mathrm{C}$ and should add by chlorine $100 \mathrm{ppm}$, this tool made for minimize the dirt and soil that still spot on the plate and glass, most of Food Street Vendors in Indonesia they knee once washing the plate and glasses, 
easy to contaminate by the animal such as cat, because they could drink the bucket without any cover, this tool high approximately 80 centimeters, that the Food Street Vendors standing up and its good for their health

Table 8. Response of Food Street Vendors to Three Buckets System

\begin{tabular}{|c|c|c|c|}
\hline NO & Component & Excellence & $\%$ \\
\hline 1. & Effectiveness of Tool & 10 & 25 \\
\hline 2. & Effectiveness of washing & 15 & 37,5 \\
\hline 3. & Cleanliness of wares & 15 & 37,5 \\
\hline \multicolumn{2}{|c|}{ TOTAL } & 40 & 100 \\
\hline
\end{tabular}

Source : Author, 2018

\section{CONCLUSION}

Food Street vendors in Indonesia are still very low level of awareness of health and hygiene, due to several main factors namely o f lack of Understanding of the importance of Health and hygiene Foods served ranging from food raw materials, storage places Raw materials Food and equipment, equipment Hygiene, Sanitation equipment Cook and utensils, up to personal hygiene; The difficulty of obtaining access to clean running water; Expensive of water supply; Premises to contamination of dust and dirt on the roadside. Health and hygiene is the right of every Human, business-based provider of Food and Beverage is required to comply with the existing regulations as regulated by Republic of health legislation and Consumer Protection, Traffickers in Indonesia especially in Bandung and Jakabaring, Palembang are still many who do not yet have accessibility of Clean Water and Flowing Water, Training and Education on hygiene and health to the Food Street Vendors and Consumers is needed to provide an understanding of the diseases that are inflicted mainly, in the face of Global competition and to win the market. Government should do investigation and monitoring periodically through Public Health and educate the Citizen, The Food Street vendor requires a sales strategy with Health and Hygiene because consumers have smart choosing products and services (hygiene) one of the factors in purchasing considerations. Three Buckets System is a solution given in cleanliness and health of serving dish with a system of three buckets is expected Stools, bacteria and germs no longer stick to dip serving that will cause cancer in the body in the long term, the Three Buckets System is also expected to provide water use solutions more effective and efficient,

\section{REFERENCE}

About Guidance Requirements Hygiene Sanitasi Food Street

Barbara Almanza,PhD,RD, and Ricard Ghiselli, PhD (2012): FOOD SAFETY "researching the Hazard in Hazardous Foods. Apple Academic Press, Toronto New Jersey 
David McSwane,H.S.D, Nancy R.Rue,Ph.D, Richard Linton,Ph.D (2003): "Essential of Food Safety and Sanitation"Pearson Education,Inc.,Upper Saddle River, Newe Jersey 07458.

Decree Minister of Health of Republic of Indonesia No 942/MENKES/SK/VII/2003

Hazard Analysis Critical Control Point Prerequisite, 1990

http://www.kumpulandefinisi.com/2015/06/pengertian-dan-definisi-pedagangkaki-lima.html, June 18, 20152018

https://she.id/article/3270/hati-hati-kandungan-sabun-pencuci-piring-bisa-picukanker-tubuh.html, May 192017 Tanti Malasari

Stanley Jhon and Stanley Linda 2015 (2015) : “Food Tourism”. CPI Group (UK) Ltd, Croydon,CR04 YY

Surono Winarno.F.G (2004) : HACCP dan Penerapannya Dalam Industri Pangan”. Embrio Press Jakarta 